\title{
САМОСВІДОМІСТЬ ЯК СКЛАДНИК МОВНОЇ КОМПЕТЕНЦЇ̈ ОСОБИСТОСТІ
}

\author{
М. І. Бобак, С. В. Бондаренко, В. Й. Кульчицький, М. Л. Кушик, Г. Б. Паласюк, \\ Г. О. Попадинець, І. А. Прокоп, А. М. Пришляк, Т. В. Саварин, В. Я. Юкало \\ Тернопільський держсавний медичний університет імені І.Я. Горбачевського
}

\section{SELF-CONSCIOUSNESS AS A COMPONENT OF LINGUISTIC COMPETENCE OF A PERSONALITY}

\author{
M. I. Bobak, S. V. Bondarenko, V. Y. Kulchytskyi, M. L. Kushyk, H. B. Palasiuk, \\ H. O. Popadynets, I. A. Prokop, A. M. Pryshliak, T. V. Savaryn, V. Ya. Yukalo \\ Ternopil State Medical University by I. Ya. Horbachevsky
}

\begin{abstract}
У статті розглянута проблема самосвідомості як складника мовної компетенції особистості. Аналізусться значення самосвідомості як центрального утворення, без якого людина не може стати особистістю. Висвітлюсться громадянська свідомість та самосвідомість, що є однісю із найважливіших складових психологічної структури особистості. Зосереджена увага на питанні зв'язку мови з мисленням людини, її внутрішнім світом та культурними цінностями. Обговорюються основні шляхи формування мовної компетенції особистості. Визначено головні ознаки мовної особистості. Окреслюється мета формування гармонійної, високо розвиненої свідомості й самосвідомості мовної особистості.
\end{abstract}

The article adduces the problem of self-consciousness as a component of linguistic competence of a personality. The notion of self-consciousness as central formation, without which a human being cannot become a personality, is analyzed. Civic consciousness and self-consciousness, which is one of the important components of psychological structure of a personality are described. A special attention is paid to the question of language and thinking relation, inner world and cultural values of a man. The basic ways of creating a personal language competence are discussed. The main features of linguistic personality are determined. The aim of formation of harmonious highly developed consciousness and self-consciousness of a linguistic personality is described.

Вступ. Тільки розвинута духовність може стимулювати продуктивну діяльність особистості бути гарантом морального і фізичного здоров'я народу. А формування особистості невіддільне від мовного розвитку, адже мова є носієм і виразником духовності індивіда і суспільства. Тому дуже важливим завданням усіх рівнів освіти в державіє формування духовної, інтелектуальної особистості, відповідальної за мовний вчинок, - справжнього громадянина України.

Основна частина. Розвинена мова людини - не тільки форма думки, а й сама думка, супутник мислення, свідомості, джерело пам'яті. Виходячи 3 настанов павловської класифікації типів вищої нервової діяльності, наявних теоретичних розробок в галузі психології іпсихолінгвістики і, головне, багаторічних спостережень у сфері практичної мови людей різних професій, різного рівня освіти, інтелектуальності, загальної культури, трудової діяльності, емоційності тощо. I. Білодіду праці “Людина іiї мова" висловив ряд міркувань щодо класифікації людської мови за типами пси- хічних механізмів усного і писемного спілкування. Аналізуючи основні типи мовлення, науковець активно оперує поняттям “мовної особистості”': "В загальному плані мовно-психічного механізму норма, комплекс, коло мовних асоціацій, узвичаєних у практиці даного мовного колективу, тобто багатство системи асоціацій певної національної мови, певної культури народу, зумовлюються всім суспільним і інтимним життям мовця; адже кожна мовна особистість більшою чи меншою мірою володіє асоціаціями побутовими, загальнокультурними, професійними, науковими, різного роду ремінісцентними (історія, лінгвістика, мистецтво, міфологія тощо). Створення ширшого чи вужчого діапазону асоціацій, уявлень зумовлюється освітою, вихованням, культурою індивідуума; активність іцілеспрямованість їх використання - це риси психічного механізму мовлення, тобто діяльності мозку, зокрема пам'яті..." [1].

Різноманітна щодо індивідуальних особливостей людська мова у своєму внутрішньому механізмі зу-

(с) М. І. Бобак, С. В. Бондаренко, В. Й. Кульчицький та ін. 
мовлена соціальними чинниками формування особистості, середовищем, в якому людина виховується, здобуває освіту, розвивається, виробляє певні навики, риси соціальної поведінки, характеру. У перші десятиліття XIX ст. В. Гумбольдт започаткував напрямок досліджень, який розробляв питання зв' язку мови 3 мисленням людини, іiі внутрішнім світом та культурними цінностями. В науці цей напрямок одержав назву антропоцентричного, що підкреслювало пріоритети психологічного й етносоціологічного елементів та концентрацію уваги на людській особистості як носії та творцеві мовної картини світу.

Історик культури й критик, лінгвіст Д. ОвсяникоКуликовський писав, що рідна мова — музика й малюнок душі людської. Саме в мові учений вбачав найголовнішу ознаку явища національності як об' єднання людей “на грунті спільної мови, що досягла певної висоти розвитку і стала психічною основою для колективної розумової діяльності... В подальшому, крізь віки культурного розвитку, національність разом $з$ мовою перетворюється в ту психологічну форму особистості, яка надає ій своєрідного душевного складу, здіймається у сферу вищу, всевладну над думкою і над чуттям, у сферу моральну" [2]. Розробку психологічного напрямку в українському мовознавстві продовжив І. Огієнко. Підвалини такого підходу були обгрунтовані ним у праці “"Українська культура": "Мова — це наша національна ознака, в мові — наша культура, ступінь нашої свідомості. Мова - це форма нашого життя, життя культурного й національного, це форма національної організації. Мова - душа кожної національності, іiі святощі, іii найцінніший скарб... Звичайно, не сама по собі мова, а мова, як певний орган культури, традиції. В мові наша стара й нова культура, ознака нашого національного визнання. Мова — це не тільки простий символ розуміння, бо вона витворюється в певній культурі, в певній традиції. В такому разі мова — це найясніший вираз нашої психіки, це найперша сторожа нашого психічного Я... " [3]. Як бачимо, мовна особистість у праці І. Огієнка постає в образі “психічного Я”. У “Науці про рідномовні обов’язки” вчений зауважує, що про духовну зрілість окремої особи і цілого народу судять насамперед з культури його літературної мови. 'Головний рідномовний обов’ язок кожного свідомого громадянина - працювати на збільшення культури своєї літературної мови" [4].

Як відомо з психології, головною ознакою особистості є наявність свідомості і самосвідомості. Тоді головна ознака мовної особистості - наявність мовної свідомості і мовної самосвідомості. Поняття мов- но-національної свідомості наближається до таких понять, як мовна картина світу, стратегія і тактика мовної поведінки. Говорячи про мовну свідомість особистості, ми повинні мати на увазі ті особливості мовної поведінки індивідуума, які визначаються комунікативною ситуацією, його мовним і культурним статусом, соціальною належністю, статтю, віком, психічним типом, світоглядом, особливостями біографії та іншими константними і змінними параметрами особистості.

Громадянська свідомість та самосвідомість є однією i3 найважливіших складових психологічної структури особистості. В ній віддзеркалюється індивідуальне суб'єктивне ставлення людини до суспільних явищ, до системи наявних суспільних цінностей, щовиступають для конкретного індивіда як об' єктивна реальність, що може за певних умов трансформуватися у власні, суб' єктивно значущі ціннісні орієнтації особистості. Важливу роль у становленні громадянської свідомості та самосвідомості особистості відіграє усвідомлення нею своєї належності до певного етносу, нації. Усвідомлення такої належності є основою виникнення етнічної, а на певних етапах розвитку спільноти чи суспільства - національної свідомості та самосвідомості особистості. Щоб збагнути роль цього феномена у громадянському становленні особистості, треба розкрити його психологічну, соціально-психологічну супність. Відомо, щопроблема самосвідомості є однією з найважливіших у дослідженні особистості. Адже самосвідомість $є$ тим центральним утворенням, без якого людина не може стати особистістю.

Тут варто згадати думку видатного психолога С. Рубінштейна про самосвідомість та іiі особливу роль у визначенні сутності особистості, зокрема, у детермінації змісту та спрямованості соціальної активності та самоактивності людини. Говорячи про таку вельми суттєву характеристику людини, як відповідальність, учений підкреслював, що “Останнє, завершальне питання, яке постає перед нами у плані психологічного вивчення особистості, це питання про iii самосвідомість, про особистість як “Я”, котре як суб' єкт свідомо присвоює собі все, що робить людина, відносить до себе всі, що виходять від неї справи та вчинки і свідомо бере на себе за них відповідальність як їх автор і творець. Проблема психологічного вивчення особистості не закінчується вивченням психічних властивостей особистості - іi здібностей, темпераменту та характеру; вона завершується розкриттям самосвідомості особистості”.

Досить тільки нагадати той незаперечний факт, що самосвідомість не лише результат, а й передумова 
розвитку свідомості і навпаки. Уже з короткого екскурсу у загальні питання самосвідомості неважко пересвідчитися, наскільки багатогранним, складним i, що найголовніше, визначальним для суті особистості феноменом є іiї самосвідомість. Більш зрозумілою і переконливою бачиться виняткова роль самосвідомості, коли йдеться про певні соціальні, суспільні, зокрема, громадянські характеристики людини - людини-громадянина, патріота, особистості, яку хвилює доля спільноти, доля нації, з якою вона себе ідентифікує. Цілком зрозуміло, що такі позитивні характеристики громадянської сутності можуть бути притаманні лише особистостям з високим рівнем розвитку національної свідомості та самосвідомості.

Передусім слід підкреслити, що для самосвідомості, об' єктом якої є характеристики людини як носія певних етнічних, національних особливостей, рис, властивостей, притаманні всі, що вже були згадані вище структурні компоненти самосвідомості: самооцінка, соціально-психологічні очікування, “образ Я" [5].

Неперервна мовна освіта має бути орієнтована на формування мовної особистості, що забезпечує розширення функцій державної мови, творення україномовного середовища в усіх сферах суспільного життя, природне бажання повернутися у своєму щоденному побутовому спілкуванні до перерваних родинних традицій, до відродження традиційної народної культури у спілкуванні, що прагне до вироблення зразків висококультурного інтелігентного спілкування шліфованою, нормованою, літературною мовою.

Національній самосвідомості конкретної особистості, як і самосвідомості усіх; представників нації, 3 якою ця особистість себе ідентифікує, притаманне прагнення до самовираження і самореалізації своєї національної сутності, неповторності, потреба зайняти гідне місце серед інших національних спільнот та зробити помітний внесок у розвиток людської історії. Цілком зрозуміло, що прагнення кожної нормальної, цивілізованої національної спільноти до виявлення та реалізації своїх національних своєрідних особливостей органічно поєднується із потребою виявляти та розвивати в собі загальнолюдські характеристики.

У гармонійній, високо розвиненій свідомості й самосвідомості людини можна відокремити низку тісно взаємопов' язаних елементів, що загалом забезпечують належний рівень ефективного функціонування цього дуже складного і важливого системного утворення у сфері духовності особистості. Одним 3 таких елементів, а водночас і чинників, що зумовлюють виникнення, функціонування та розвиток націо- нальної самосвідомості, є національна ідентифікація, тобто усвідомлення людиною своєї належності до певного етносу, нації, усвідомлення своєї близькості 3 нацією, спорідненості з нею.

Є ще одна невід'ємна властивість мовця, одна 3 обов'язкових його характеристик. Йдеться про любов кожної людини до своєї мови. Це почуття живе глибоко в душі кожного носія мови, як один із виявів любові до Батьківщини.

Відомо, що моральні цінності, їх дієвість виявляються перш за всеу спілкуванні людей, у їх взаємному ставленні, у ставленні кожної людини до себе самої. Водночас моральні цінності визначають сутність ставлень людини до будь-яких інших явищ 1 детермінують характер усій сфері людської життєдіяльності. Чи не найбільшою мірою це стосується ставлення людини до праці. Усвідомлення працелюбства як вищої моральної цінності є одним з найсуттєвіших свідчень високої духовності людини. Той, хто збагнув цю істину, ставиться до праці не лише як до засобів забезпечення матеріального достатку, а й усвідомлює благотворний вплив праці на людину, на розвиток їі здібностей, волі, характеру. Він вбачає в праці невичерпне джерело натхнення, мук і радощів творення, творчих злетів. Людина, яка знаходиться на високому рівні свого особистісного i, зокрема, громадянського розвитку, неодмінно відзначається сформованістю громадянських цінностей, серед яких особливе місце посідають ті, що є визначальними у структурі національної свідомості та самосвідомості.

Висновок. Отож, найбілышою цінністю є патріотизм, що втілюється у самовідданій любові до рідної землі, іiі народу, Батьківщини. Особистість, яка є патріотом, уболіває за долю Вітчизни, переживає дієву потребу віддавати всі свої сили служінню співвітчизникам, своїй нації. Почуття відповідальності за сучасне й майбутнє нації, держави є для неї реальним виявом громадського обов'язку. Вона прагне збагнути як величні, героїчні етапи в історії Батьківщини, так і причини появи періодів трагічних занепадів i зумовлені цим страждання народу. 3 шаною ставиться до видатних людей, національних героїв, які жертовно служили своєму народові, збагачували його культуру, науку, примножувати внесок Вітчизни у скарбницю світової цивілізації. Не буде перебільшенням, якщо сказати, що серед громадянських цінностей чи не найважливіше значення має усвідомлення особистістю виняткової ролі у житті людини, суспільства, держави мови, у якій на генетичному рівні втілюється ментальність народу, його поступ, сподівання, віра та воля. 